Marquette University

e-Publications@Marquette

Theology Faculty Research and Publications

Theology, Department of

$1-1-1985$

Luke 22:14-38 and Greco-Roman and Biblical Farewell Addresses

William Kurz

Marquette University, william.kurz@marquette.edu

Published version. Journal of Biblical Literature, Vol. 104, No. 2 (1985): 251-268. Publisher Link. (C) 1985 Society of Biblical Literature. Used with permission. 


\title{
LUKE 22:14-38 AND GRECO-ROMAN AND BIBLICAL FAREWELL ADDRESSES
}

\author{
WILLIAM S. KURZ, S.J. \\ Marquette University, Milwaukee, WI 53233
}

Several questions about Luke 22:14-38 remain after synoptic comparison, source studies, and focus on its individual pericopes. They include textual problems, speculation about the cup-bread-cup order, questions why the author of Luke-Acts (henceforth simply "Luke") included the dispute about greatness here, explanations for Luke's unique mention of Jesus' bequeathing the kingdom to his disciples, and attempts to explain the peculiar statement about having a purse and a sword (Luke 22:35-38). Reading the whole passage in the light of ancient farewell speeches clarifies some of these cruces interpretum.

The ancient "farewell address" provides a structure into which to fit such apparently unrelated pericopes. The genre helps to explain why Luke moved the prediction of Judas's betrayal and the dispute over greatness to where he did. The way the genre serves to explain new situations after a founder's death helps to account for the apparent reversal of instructions from Luke 9 and 10 in Luke 22:35-38.

This article will illustrate how a collection of traditional sayings of Jesus combines in Luke 22:14-38 to form a farewell speech. It will compare this speech to other farewell addresses in Greco-Roman and biblical traditions, regarding both its form and its functions. The thesis it proposes is that Luke 22:14-38 imitates farewell speeches in the biblical tradition for readers in a Hellenistic culture.

Although some scholars have mentioned Luke 22:14-38 as an example of the ancient farewell address, ${ }^{1}$ the passage has received far less attention from this standpoint that the more obvious farewell speech in

1 J. Ernst, .Das Evangelium nach Lukas (RNT; Regensburg: Pustet, 1977) 589; E. LaVerdiere, "A Discourse at the Last Supper," TBT 71 (1974) 1540-48; J. P. Kealy, The Cospel of Luke (Denville, NJ: Dimension, 1979) 413. For analysis into the preexistent blocks of material, see esp. H. Schürmann, Der Einsetzungsbericht Lk 22, 19-20 (NTAbh 20.4; Münster: Aschendorff, 1955) and his Jesu Abschiedsrede $L k$ 22,21-38 (NTAbh 20.5; Münster: Aschendorff, 1957). A brief popular summary of his results is his Der Abendmahlsbericht Lucas 22,7-38 (Schriften zur Pädogogik und Katechetik 9; Pạderborn: Schöningh, 1955). 
Acts $2017-38^{2}$ Others have also compared the farewell addresses in Luke-Acts with those in the OT and the Apocrypha ${ }^{3}$ But few have noticed that Luke treats the speech at the Last Supper as Jesus' counterpart of Paul's farewell address in Acts 20 This may be because it consists mostly of traditional sayıngs gathered together and because there is some dialogue instead of the monologue in Acts 20 Most of the commentaries and treatments of Luke 22 focus on the institution narrative and on the problem of the authenticity of the sayings attributed to Jesus 4

The hypothesis underlying this article is that Luke had enough rhetorical training to recognize and imitate a literary form and genre such as the farewell address ${ }^{5}$ Finding this literary form both in his GrecoRoman milieu and in the Greek Bible which he was consciously imitating, ${ }^{6}$ Luke gave his readers what they would expect-a farewell speech by Jesus before his death

I am not arguing that Luke used any one farewell speech as his exemplar Rather, from his familiarity with many farewell speeches, he gave Luke 22 a "biblical flavor" by alluding especially to Greek OT

2 See the major studies by J Dupont, Le Discours de Milet Testament Pastoral de Saint Paul (Actes 20,18-36) (LD 32, Paris Cerf, 1962), H -J Michel, Die Abschredsrede des Paulus an die Kirche Apg 20,17-38 (SANT 35, Munich Kosel, 1973), E Cortès, Los Discursos de Adiós de Gn 49 a Jn 13-17 (Colectánea San Paciano 23, Barcelona Herder, 1976) 400-425 on Acts 20, nothing on Luke 22, H Schurmann, "Das Testament Paulus fur die Kurche Apg 20,18-35" in his Traditionsgeschichtliche Untersuchungen zu den synoptischen Evangelien (Dusseldorf Patmos, 1968) 310-40, with bibliography p 310 n 1, p 335 n 137

${ }^{3} \mathrm{Eg}$, Michel, Abschiedsrede, Dupont Discours, Cortès, Adıós, J Munck, "Discours d adıeu dans le Nouveau Testament et dans la littérature biblıque," Aux Sources de la traditıon chrétıenne Mélanges offerts à M Maurce Goguel (Bıblıthèque théologıque, Neuchâtel and Parıs Delachaux \& Niestlé, 1950) 155-70, esp 159 and 167-70

$4 \mathrm{Eg}$, Schurmann's works in $\mathrm{n} 1$, J Jeremias, Die Sprache des Lukasevangeliums Redaktion und Tradition $2 m$ Nicht-Markusstoff des dritten Evangeliums (MeyerK Sonderband, Gottıngen Vandenhoeck \& Ruprecht, 1980) 286-93, J Jeremıas, The Eucharistic Words of Jesus (Philadelphia Fortress, 1977), V Taylor, The Passion Narrative of St Luke (SNTSMS 19, Cambridge Unıversity Press, 1972) 47-68, I H Marshall, The Gospel of Luke (New International Greek Testament Commentary, Grand Rapids Eerdmans, 1978) 792-827

5 On Luke's rhetorical training and ability, see W S Kurz, "Hellenistic Rhetoric in the Christological Proof of Luke-Acts," CBQ 42 (1980) 171-95, BDF p 2, \$3, and a forthcoming dissertation by Willam R Long, "The Trial of Paul in Acts Historical, Literary and Theological Considerations" (Brown University)

6 See E Richard, Acts 6 1-8 4 The Author's Method of Composition (SBLDS 41, Missoula, MT Scholars Press, 1978), W S Kurz, "Luke-Acts and Historiography in the Greek Bible, Society of Biblical Literature 1980 Seminar Papers (ed P J Achtemeier, Chico, CA Scholars Press, 1980) 283-300, and biblography cited esp p 297 n 10 See also E Haenchen, The Acts of the Apostles (Philadelphia Westminster, 1971) 591, H Conzelmann, Die Apostelgeschichte (HNT 7, 2d ed, Tubingen Mohr [Siebeck], 1972) 126, 127, 129, Ernst, Lukas, 599 For examples of non-biblical literature to which Luke 22 is akın, cf Conzelmann, $A_{p g}^{2}, 127,128$, and Ernst, Lukas, 589, 594 
farewell speeches. ${ }^{7} \mathrm{~A}$ modern comparison might be the biblicism and King James English in some contemporary sermons. Nor will I join the discussion of the sources of Luke 22:14-38. It seems more likely that Luke gathered unrelated sayings into the farewell speech form for his Last Supper account than that some unknown editor had already done this. Therefore, the arguments that Luke modified Mark in the light of other traditional material (closer to 1 Corinthians 11) seem more probable than that he simply replaced Mark with a preexisting complex in vv 14-38. But my thesis is about the present arrangernent of the sayings of Jesus in the form of a farewell address, whether produced by Luke or his source. Greco-Roman symposium discussions probably also influenced Luke 22:14-38. ${ }^{8}$ But the frequency with which Luke imitates and alludes to his Greek Bible suggests that biblical farewell addresses were his primary models.

This article will use the following steps to demonstrate the thesis it advances, that Luke 22:14-38 imitates biblical farewell speeches for readers in a Hellenistic culture. It will first describe forms of farewell address-Greco-Roman (like the testament of Socrates in Plato's Phaedo) and biblical (which were imitated in Josephus and intertestamental literature as well as in Acts 20 and the NT)-and then compare Luke 22:1438 especially with 1 Macc 2:49-70 and 1 Kgs 2:1-10, prime examples of the genre that seem also to have influenced Luke 22 directly. A chart will summarize the evidence and illustrate elements of the farewell address in Greco-Roman and biblical farewell speeches. The article will also briefly compare the functions of other farewell addresses with those in Luke 22. Throughout, it will apply insights from the genre to parts of the passage that have perplexed commentators.

\section{Forms of the Farewell Address}

\section{A. Greco-Roman}

Socrates' farewell dialogue in Plato's Phaedo had great influence on the Greco-Roman farewell address. The genre highlighted the speaker's

7 C. H. Talbert's review criticized Michel for limiting his study, Abschiedsrede, to biblical and Jewish authors without treating Greco-Roman writers (JBL 94 [1975] 145). This article does investigate the latter, but the evidence still suggests closer imitation of the biblical examples.

8 See Ernst, Lukas, 589. The situation of a dialogue at table is never lost sight of in Luke 22 and leads into the Eucharist, with the model of the symposium between Socrates and his disciples probably also in the background. Two dissertations on this topic are P. E. Leonard, "Luke's Account of the Lord's Supper Against the Background of Meals in the Ancient Semitic World and More Particularly Meals in the Gospel of Luke" (Diss., Manchester, 1976) and W. Boesen, "Das Mahlmotiv bei Lukas: Studien zum lukanischen Mahlverständnis unter besonderer Berücksichtigung von Lk 22,14-20" (Diss., Saarbrücken, 1976), which were not available to me. 
impending death, care of those remaining, regulation of discipleship, thanks to the gods, an accounting for his life, consolation to an inner circle of followers, didactic speeches, and political and philosophical testaments. ${ }^{9}$

As a model for farewell address, the Phaedo is much like Deuteronomy. The Phaedo presents the last words of Socrates, as Deuteronomy purports to be Moses' farewell. Both are classical examples of the genre, but as paradigms they fail to be as clear-cut as shorter, exclusively farewell speeches like $1 \mathrm{Kgs}$ 2:1-10. Both include important aspects of their heroes' teaching in long discourses that have little to do with the setting of impending death. As Moses' farewell has to be extracted from long sections of Torah, so does Socrates' from a long dialogue on the soul's immortality.

Because the Phaedo inspired so many imitations, the elements of its farewell speech are worth recalling. The setting of the dialogue before Socrates' execution adds solemnity to its teaching about the immortality of the soul. It purports to be Socrates' last teaching in philosophy, which he describes as practicing for being dead, since philosophy teaches how to ignore bodily distractions (Phaedo $80 \mathrm{E}-81 \mathrm{~A}$ ).

The following exchanges have many expressions in common with Luke's preface. In 59D, Phaedo says, "I will try to diēgèsasthai" about Socrates' death. Echecrates responds, "so try to akribestata diexelthein everything. ..." In 59C Phaedo promises, "I will try to tell you everything from the beginning (ex archēs ... diēgésasthai)." Both Plato and Luke are concerned with narrating accurately what happened from the beginning.

Allusions to Socrates' impending death pervade the dialogue (61B, $63 \mathrm{D}, 69 \mathrm{D}, 85 \mathrm{~B}, 89 \mathrm{~B})$. The sections from 115 to the end in 118 contain many of what will become the standard elements of a farewell speech. Socrates wants to take his bath before the poison comes, so the women will not have to wash his dead body (115A). Crito asks if Socrates has last directions concerning his children or burial (115B-C). Those to be left behind talk of their misfortune in losing one "like a father to us" (116A). Socrates has the women and his children come, and he gives them his last directions; he then sends them away (to avoid displays of grief) and turns to his friends (116B). Socrates gives a final example and teaching by correcting his friends who urge him to put off the poison (116D$117 \mathrm{~A})$. Before drinking the poison, Socrates prays to the gods that his departure be fortunate: "so I offer this prayer and may it be granted (genoito)" (117C). After watching him drink the poison, his friends break into tears and are rebuked by Socrates (117C-E). The dialogue reports Socrates' last words before he died, instructions to Crito to offer a

9 E. Stauffer, “Abschiedsreden,” RAC 1 (1950) 29-35, col. 29. 
cock to Asclepius, the god of healing (in thanksgiving for his death). Phaedo's final statement is a brief encomium on Socrates as "the best and wisest and most righteous (dikaiotatos) man" (118).

As the chart in section $\mathrm{C}$ will illustrate, Greco-Roman writers tended to ornament their narratives with farewells that involved these and similar elements, but few extant samples combine very many into long farewell discourses. As in many ancient biographies, authors stressed witty and memorable sayings of their heroes. They were especially fond of "last words," "ein kurzer Satz des Sterbenden, der die Endsumma seines Lebens enthält." 10 For example, in Plutarch's Pericles 38.3-4, to those praising the dying Pericles' deeds and trophies as general, he retorts that he is amazed that they are praising what is pros tychen and common to many generals but fail to mention what is best of all: "for no living Athenian ever put on mourning because of me" (LCL 3, p. 110). In his study of such last words, Willibald Schmidt notes their use as ornaments in writing histories (except in the tradition of Thucydides and Polybius), in lives (as by Diogenes Laertius), in the Iliad, in Greek tragedies and epigrams, and in Vergil. ${ }^{11}$ What schoolboys learned in school they later used as authors, namely, creating speeches and letters for famous men:

Nam quae pueri et adulescentes in scholis didicerant, postea scriptores facti in operibus adhibebant. Didicerant autem ibi etiam virorum clarorum verba fingere. Perseum puerum scholam effugisse scimus, ne Catonis ad mortem parati orationem ediscere cogeretur. Hac, quam adulescentes adepti erant, arte postea in operibus usi sunt. ${ }^{12}$

Among the kinds of last words Schmidt mentions, many fit the patterns of farewell addresses in the tradition of Plato's Phaedo: The speaker (1) gives commands or names successors; (2) exhorts, urges disciples to remember his teachings; (3) sometimes curses enemies; (4) proclaims innocence or fulfillment of office; (5) defends what he did or why he is about to commit suicide; (6) reflects on his life; (7, rarely) seeks clemency; (8) shows courage facing death; (9) sometimes expresses sorrow; $\left(10\right.$, infrequently) turns over soul to gods. ${ }^{13}$

\section{B. Biblical Forms and Variations}

Stauffer cites biblical differences from the preceding, such as a lack of initiation into the ars moriendi. In the Bible, the one giving the farewell

10 Ibid.

11 W. Schmidt, De Ultimis Morientium Verbis (Diss., U. Marburg; Marburg: Chr. Schaaf, 1914) 8-9, 15-22.

12 Ibid., 37-38. Cf. the use of progymnasmata in ancient education in Kurz, "Rhetoric," 186, 192-94.

${ }^{13}$ Schmidt, Ultimis Verbis, 54-63. 
speech is a man of God guided by God rather than a god-man neither fully human nor fully divine. Elements Stauffer lists are revelations of the speaker's coming death, final orders, installation of his successor, a speech to the people about his life, warnings for the future, and woes or consolations. ${ }^{14}$ Famous examples of this tradition are Deuteronomy, Tob 14:3-11, and The Testaments of the Twelve Patriarchs. Luke's Greek Bible had several farewell addresses. The Hebrew Bible has many farewell speeches, but I stress the Greek because of the consensus that Luke used the Greek. For farewell addresses, the most significant differences of the Greek Bible are examples found in later books not extant in the Hebrew Bible (like Maccabees and Tobit). Some of the later examples are closer to Luke than earlier speeches, in style as well as in time and culture. The fact that some Greek biblical books (e.g., Maccabees) have Hellenistic origins also undercuts dichotomies often made between Judaism and Hellenism. ${ }^{15}$ Some translation decisions in the Greek Bible may also be affected by Greco-Roman rhetoric of farewell addresses, but to illustrate that is beyond the purpose of this paper.

Besides the Greek Bible, one important parallel for the farewell address in Luke 22:14-38 is that of Paul in Acts 20:17-38. This is not to argue that Acts was written first, but it does imply that Luke and Acts were conceived as a two-volume work and that the plan for Acts was influential in the way the first volume was written. ${ }^{16}$ (For example, Luke

14 Stauffer, "Abschiedsreden," 31. Compare the characteristic traits of a farewell address in Munck ("Discours," 159, 167-70) and the thirteen characteristics in Michel (Abschiedsrede, 47-54) plus the order of motifs (p. 54), and theological meaning and Sitz im Leben of the genre (pp. 54-57). For a summary of the genre of the testament in the intertestamental literature, see E. v. Nordheim, Die Lehre der Alten: I. Das Testament als Literaturgattung im Judentum der Hellenistisch-Römischen Zeit (ALGHJ 13; Leiden: Brill, 1980) 229-42, with bibliography following.

The biblical literature also has farewell speeches at epiphanies of God or angels, for example, Raphael's in Tobit. This example is similar in structure to nonbiblical epiphanies of gods, but is an angelic doxology of God's work, to which Tobias's response is a hymn to God (Stauffer, "Abschiedsreden," 31-32).

15 See the classic by M. Hengel, Judaism and Hellenism (Philadelphia: Fortress, 1974) 1. 95-106 and full bibliographical notes 2. 65-71. For critiques of Hengel, see L. Feldman, "Hengel's Judaism and Hellenism in Retrospect," JBL 96 (1977) 371-82; and J. Goldstein, "Jewish Acceptance and Rejection of Hellenism," in Jewish and Christian Self-Definition 2: Aspects of Judaism in the Graeco-Roman Period (ed. E. P. Sanders et al.; Philadelphia: Fortress, 1981) 64-87, notes pp. 318-26. Cf. M. Hengel, Jews, Greeks and Barbarians (Philadelphia: Fortress, 1980) esp. new material pp. 49-126, notes pp. 152-74.

16 See C. H. Talbert, Literary Patterns, Theological Themes and the Genre of Luke-Acts (SBLMS 20; Missoula, MT: Scholars Press, 1974) 141-43, esp. p. 141: “A compositional procedure modelled after . . . Aristotle's Poetics 17:5-10, in Suetonius' Life of Vergil 22-23, in Lucian's How to Write History 48, and in Pliny's Letters 9:36. In this procedure an author begins with an overall conception of the whole, represented on occasion by a preliminary summary sketch divided into its major parts. He then fills out the parts in light of the total 
postponed to Acts 6:12-14 mention about false witnesses at the Sanhedrin trial and emphasized Herod in the passion in preparation for Acts 4:25-28.)

The main source for much of Luke's Gospel, Mark, did not have a developed farewell address at the Last Supper. Apparently, some of the sayings found in Luke's farewell address at the Last Supper have been inspired by, if not moved from, elsewhere in Mark (e.g., Luke 22:25-26 seems a variant inspired by Mark 10:42-44). ${ }^{17}$ It is reasonable to suggest that Luke's plan to have a farewell address by Paul in Acts 20 may have inspired him to insert a parallel one by Jesus here, since there is so much evidence for parallelism between Jesus and Paul in Luke-Acts. ${ }^{18}$ Acts 20 is more or less a unity, whereas Luke 22:14-38 consists of independent sayings that have been woven together into a speech. An important difference is that Paul's is a monologue, Jesus' a dialogue. The dialogue form, especially with the disciples' misunderstanding (Luke 22:24,38), is reminiscent of Socratic dialogues as well as biblical dialogues like Joshua 23-24 and 1 Samuel 12.

The introduction has suggested, and a chart will illustrate, that Luke 22 has elements from several farewell speeches, rather than mimicking any one speech. Luke 22 imitates the perceived genre of "farewell address" especially in its biblical forms. But prime examples of those forms, on which Luke seems to be directly dependent for some details, are 1 Macc 2:49-70 (which Acts 20:17-38 also imitates) and $1 \mathrm{Kgs}$ 2:1-10.

The following basic structure of a farewell dialogue is found in Luke 22:14-38. (1) Jesus refers to his imminent death (22:15-18), (2) instructs

conception." Talbert sees such a unified conception behind Luke and Acts, abundantly illustrated by the many parallels between the two books (passim). H. J. Cadbury had argued similarly: Luke and Acts "are not merely two independent writings from the same pen; they are a single continuous work. Acts is neither an appendix nor an afterthought. It is probably an integral part of the author's original plan and purpose" (The Making of Luke-Acts [London: SPCK, 1968] 8-9).

17 F. W. Beare interprets this passage as a development of Mark 10:43-44 (The Earliest Records of Jesus [Nashville: Abingdon, 1962] 227). The case is highly debated. See Schürmann, Abschiedsrede, 63 n. 213 for those pro and con. Schürmann himself (ibid., 63-99), Taylor (Passion, 62-64), Marshall (Luke, 811), Ernst (Lukas, 592) all argue for a nonMarcan source. Schürmann's argument that Luke does not suppress doublets in advance (e.g., Abendmahlsbericht, 104 n. 25) seems insufficient to deny it in Luke's parallel position to Mark 10:43-45, since the false witnesses at Jesus' Sanhedrin trial are suppressed there and mentioned in Stephen's trial in Acts 6:13-14. However, the source question is not our concern, except as it affects the structure of the speech.

18 E.g., W. Radl, Paulus und Jesus im lukanischen Doppelwerk: Untersuchungen zu Parallelmotiven im Lukasevangelium und in der Apostelgeschichte (Europäische Hochschulschriften 23/49; Frankfurt: P. Lang, 1975); Talbert, Literary Patterns. An example of a Pauline pattern from Acts applied to Jesus in the Gospel is Luke 4:16, whose wording (kata to eiōthos aut $\overline{\text { ) }}$ ) and structure is made parallel to Paul's coming to the synagogue in Thessalonica in Acts 17:1-2. 
the disciples to share the eucharistic bread and wine "eis tēn emèn anamnēsin" (22:19-20), and (3) within the eucharistic words refers to "the new covenant" through his blood shed for them (22:20). (4) Jesus predicts his betrayal and the disciples react (22:21-23). (5) The disciples' mistaken dispute over rank introduces paraenesis to exercise authority as Jesus does (22:24-27). (6) Jesus then transfers his authority to the twelve $(22: 28-30),{ }^{19}$ and (7) singles out Simon for the special mission of strengthening his brothers (as their leader), despite Simon's predicted denial of Jesus (22:31-34). Finally, (8) Jesus exhorts his disciples to a new readiness for the impending crisis and, when they misunderstand him, ends the farewell dialogue abruptly.

1 Maccabees 2:49-70. Although Dupont has compared this passage to Acts $20: 17-38^{20}$ and not to Luke 22:14-38, it seems also to have affected the redacting of the latter. The Maccabean and Lucan speeches have a similar order: (1) situation of crisis, (2) giving one's life for the covenant, (3) receiving glory, (4) exhortation to courage when challenged, (5) naming of Simon as successor (over his "brothers"), and (6) instructions to rally the faithful.

(1) Approaching death (1 Macc 2:49), Mattathias announces, "it is a time (kairos) of ruin and furious anger" (RSV). The corresponding crisis in Luke 22 includes Jesus' death (vv 15-20), betrayal by Judas (vv 2123), and denial by Peter (vv 31-34). Verses 35-38 announce a new time of the sword.

(2) Mattathias exhorts his sons to have zeal for the law, "kai dote tas psychas hymōn hyper diathēkēs paterōn hēmōn kai mnèsthēte ta erga tōn paterōn" (1 Macc 2:50-51). Perhaps Luke heard the resemblance between 1 Maccabees and the eucharistic words, which imply Jesus' giving of his life for the covenant in the same relative position in Luke 22: "Touto estin to sōma mou to hyper hymōn didomenon. Touto poieite eis tèn emèn anamnèsin. . . Touto to potērion hē kainē diathèkē en tō haimati mou to hyper hymōn ekchynnomenon" (vv 19-20). ${ }^{21}$

19 See S. Brown, Apostasy and Perseverance in the Theology of Luke (AnBib 36; Rome: Biblical Institute, 1969) 65: though the kingdom conferral (22:29) parallels post-Easter commissions in Matthew 28:18-19 and John 20:21, the pre-Easter setting is more dramatic as an unconditional grant of authority even before Jesus' passion. Matthew 28 is a farewell speech by the risen Lord. The speech in Luke 22 is grounded in the earthly Jesus.

20 Dupont, Discours, 13-15.

21 Acceptance of vv 19b-20 as genuine is increasing. See the evidence in B. Metzger, $A$ Textual Commentary on the Greek New Testament (New York: UBS, 1971) 173-77; and the argumentation for authenticity from text, literary, and form criticism and from firstand second-century liturgical practices by $H$. Schürmann, "Lk $22,19 \mathrm{~b}-20$ als ursprüngliche Textüberlieferung," in his Traditionsgeschichtliche Untersuchungen, 159-92, with an update on later bibliography pp. 191-92. See now also J. A. Fitzmyer, The Gospel According to Luke (I-IX): Introduction, Translation, and Notes (AB 28; Garden City, NY: Doubleday, 1981) 130-31. Confirming evidence of their authenticity comes from the 
(3) Both speeches promise glory (1 Macc 2:51 and Luke 22:29-30). Luke 22 leads up to this promise by the dispute over greatness and teaching on authority. By following a lesson on service with a promise of glory Luke (consciously or not) parallels Mattathias' exhortation to his sons to give their lives and so obtain glory. The statement that the disciples have remained with Jesus in his trials in Luke 22:28 seems more appropriate for the situation of Acts than of the Last Supper. The farewell address setting helps explain it. (Cf. also Luke 22:28, "You . . . remained with me en tois peirasmois mou," and 1 Macc 2:52, "Abraam ouchi en peirasm $\bar{Q}$ heurethē pistos?")

(4) Courage in trials follows the promises in both speeches. 1 Macc 2:61-62 assures "hoti pantes hoi elpizontes ep' auton ouk asthenesousin," followed by "and do not fear the words of a sinful man." In Luke 22:31-32 Jesus warns Simon that Satan will test him, but he prayed "hina mē eklipē he pistis sou." His prediction of Peter's denial (v 34) is fulfilled in vv 54-62 when Peter is afraid of three bystanders' questions.

(5) Mattathias next chooses two from among his sons to succeed him. "Kai idou Symeōn ho adelphos hymōn ... autou akouete pasas tas hèmeras, autos estai hymōn patēr. Kai Ioudas Makkabaios ... autos estai hymin archōn stratias kai polemēsei polemon laōn" (1 Macc 2:6566 ). It seems significant that Luke reverts to Simon here, from his more usual use of Peter, and uses the expression "your brothers" for the other disciples. "Simōn, Simōn . . . kai sy epistrepsas, stêrison tous adelphous sou" (Luke 22:31-32). (Both texts single out a Simon and a Judas, though in different lights.)

(6) Mattathias's last charge is "to rally about you all who observe the law" (RSV). Jesus charges Simon to strengthen his brothers (Luke 22:31-32 fulfilled in Acts 1-2 with the gathering of the 120). However, the setting in Acts differs radically from the situation of vengeance in 1 Maccabees.

Luke had deferred from chap. 22 the usual blessing at the end of a farewell speech (e.g., 1 Macc 2:69) and notice of death and mourning (e.g., 1 Macc 2:70). The blessing comes before the risen Jesus departs at the end of the Gospel (Luke 24:50-51). Luke's is the only Gospel to mention the people mourning after Jesus' death (Luke 23:48). This is not to claim Luke is imitating 1 Macc 2:69-70 in Luke 24:50-51 and 23:48. But one can suggest that similar elements of farewell addresses have influenced both the Lucan and Maccabean passages.

parallel Acts 20 farewell speech: "tèn ekklèsian tou theou, hèn periepoiēsato dia tou haimatos tou idiou" (Acts 20:28). Though the disputed words in Luke 22:20 are not considered Lucan theology, they can be seen as "unassimilated source material" from Luke's liturgy, which he was less free to change than other material. See W. S. Kurz, "Acts 3:1926 as a Test of the Role of Eschatology in Lukan Christology," Society of Biblical Literature 1977 Seminar Papers (ed. P. J. Achtemeier; Missoula, MT: Scholars Press, 1977) 30923, pp. 309, 313-18. 
1 Kings 2:1-10. Another speech that throws light on Luke 22 is David's to his son and successor Solomon. Though it does not share as many elements with Luke 22 as the Mattathias speech, some common parts help explain cruces interpretum in the Lucan passage. As 1 Kings 2 focuses on David's successor, Luke 22 addresses the twelve and especially Peter. The speeches share four elements in the same order: (1) impending death, (2) covenant with God, (3) succession to the throne(s), and (4) initial tasks for Solomon and Simon upon assuming leadership.

(1) Before his death, David summons and exhorts Solomon to carry on what David commands him (1 Kgs 2:1-3). In a different meal setting, Luke 22:14-18 stresses Jesus' impending death at a last passover together.

(2) In 1 Kgs 2:2-4, David exhorts Solomon to fidelity to God, "tou poreuesthai en tais hodois autou," to keep his commands and "ta krimata ta gegrammena en nomō Mōyseōs." Fidelity is required so God will confirm his promise to David: "ouk exolethreuthēsetai soi anēr epanōthen thronou Israēl." The same relative place in Luke 22:19-20 shows Jesus giving the twelve the Eucharist and commanding, "Touto poieite eis tèn emèn anamnèsin." The cup parallels the Mosaic law as "new covenant."

(3) After vv 21-27 (which have no correspondence in $1 \mathrm{Kgs} 2: 1-10$ ), Luke 22:28-30 promises, "Kago diatithemai hymin kathōs dietheto moi ho patēr mou basileian, hina esthēte kai pinete epi tēs trapezēs mou en tę basileia mou, kai kathēsesthe epi thronōn tas dōdeka phylas krinontes tou Israell." The pattern is similar: God gave the kingdom first to David, then to his son, and promised a Davidid would always be on Israel's throne; so God gave the kingdom to Jesus, and Jesus to the twelve, who will have eternal thrones and judge Israel.

(4) Both speeches enjoin tasks for after the speaker's death. Solomon is to punish Joab and Shimei for sins against David and to reward the sons of Barzillai for fidelity to David when Absalom revolted. The wording of the latter has intriguing echoes in Luke 22:30. The sons "esontai en tois esthiousin tèn trapezan sou" (1 Kgs 2:7). Jesus' promise to those who remained faithful "en tois peirasmois mou" is "hina esthète kai pinète epi tēs trapezēs mou" (Luke 22:30). Like Solomon, Simon has a task (strengthening his brothers, Luke 22:31-32).

Besides these four similarities, both speeches give directions for a dramatic reversal in situation after the speakers' deaths. Solomon's tasks of vengeance flow from the difference between David's lifetime, when he was bound not to take revenge, and Solomon's, who was not so bound. This reverses Joab's and Shimei's situations. Luke 22:35-38 has consistently perplexed commentators and contributed to theories of temptation-free 
epochs. ${ }^{22}$ Luke elsewhere compares Jesus and David (e.g., Luke 20:41-44, Acts 2:29-36). Echoes of David's testament to Solomon are heard here, especially when God "bequeathed" (dietheto) the kingdom to Jesus, who then willed it to the twelve (Luke 22:29), and the eating at table (1 Kgs 2:7 and Luke 22:30). They suggest that Luke may have had the reversal of David's and Solomon's times in mind when including vv 35-38 here. ${ }^{23}$ The time of relative peace in Jesus' lifetime will be followed by a time of hostility.

Few of the Greco-Roman passages that scholars mention in their treatments of farewell addresses have very full examples of the form. Most focus on a "last word," often a poignant, final saying, rather than giving a full speech. In fact, the Lucan example which W. Schmidt compares to GrecoRoman last words is Luke 23:46: "Father, into your hands I commit my spirit," not the farewell address of Luke 22:14-38. ${ }^{24}$ The fullest parallel to biblical versions of the form is Socrates' farewell in Plato's Phaedo. The only other examples with more than a few farewell speech elements are Plutarch Cato Minor 66, Plutarch Otho 15-17, Diogenes Laertius Epicurus 10:16-18 (including his will, 10:18-21, and his last letter, 10:22), and passages from Josephus, like Ant. 4.8.45-49 $\$ \$ 309-31$ (Moses' farewell, mixing biblical and Greek rhetorical elements).

Comparison of large numbers of Greco-Roman death scenes and farewell words and speeches with biblical and postbiblical examples shows two variant streams of farewell address. They differ significantly in tone, situation, vocabulary, and rhetoric. In Greco-Roman literature, the speakers of farewell addresses are generally statesmen or philosophers. They show much concern with suicide, the meaning of death, questions about noble deaths, and life after death. Most of this is alien to deaths and farewells in the biblical traditions. Conversely, Greco-Roman death scenes lack the strong biblical emphasis on God's plan, people and covenant, or on theodicy and theological interpretations of history.

Though Luke 22 and Acts 20 share many elements with Plato's Phaedo, both are clearly in the biblical tradition of farewell speeches, and in tone and content and style have more in common with biblical than with secular farewell addresses.

22 Beare, (Earliest Records, 228) calls Luke 22:35-38 the "despair of commentators," and is reduced to suggesting "stray Zealot phrases" (p. 229). Compare the famous temptationfree "Mitte der Zeit" in H. Conzelmann, The Theology of St. Luke (New York: Harper \& Row, 1961) 80-83, 103 n. 1, 232-34.

${ }^{23}$ Later I shall discuss a possible apologetic function vis-à-vis Paul's missionary practice that differed from the directives of Luke 9 and 10.

24 Schmidt, Ultimis Verbis, 64. 


\section{Chart: Elements of Farewell Addresses Selected Examples}

\begin{tabular}{|c|c|c|c|c|c|c|c|c|c|}
\hline & A20 & $\mathrm{L} 22$ & $\begin{array}{r}\mathrm{BI} \\
1 \mathrm{Mc}\end{array}$ & $\begin{array}{l}\text { BLIC } \\
1 \mathrm{~K} 2\end{array}$ & D31 & Jsh & $1 \mathrm{Sm}$ & $1 \mathrm{Ch}$ & T14 \\
\hline 1 summons successors & * & & * & * & * & * & & * & \\
\hline 2 own mission/example & * & * & $(\mathrm{F})$ & & & $*$ & * & * & \\
\hline 3 innocence/did job & $*$ & & & & $(*)$ & & * & & \\
\hline 4 impending death & * & * & & * & * & $*$ & & * & \\
\hline 5 exhorts & $*$ & * & $*$ & * & * & $*$ & * & * & * \\
\hline $\begin{array}{l}6 \text { warnings/final } \\
\text { injunctions }\end{array}$ & * & $*$ & * & * & * & $*$ & * & * & $*$ \\
\hline $7 \overline{\text { blesses }}$ & * & * & $*$ & & * & & & & \\
\hline 8 farewell gestures & * & & & & & & & & \\
\hline 9 tasks for successors & * & $*$ & $*$ & * & $(*)$ & & & $*$ & \\
\hline 10 theo review of $\mathrm{Hs}$ & & & & & * & $*$ & $*$ & & \\
\hline 11 reveals future & $*$ & $*$ & 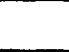 & & $*$ & $*$ & & & $*$ \\
\hline 12 promises & & $*$ & * & * & * & $*$ & & * & $*$ \\
\hline $\begin{array}{l}13 \text { appoints/refers to } \\
\text { successor }\end{array}$ & $(*)$ & * & * & * & * & & $(*)$ & * & \\
\hline 14 the rest bewail loss & $*$ & & $*$ & & * & & & & \\
\hline 15 future degeneration & * & $(\mathbf{R})$ & * & (R) & $*$ & $*$ & $*$ & & \\
\hline $\begin{array}{l}16 \text { (sacrifices) renew } \\
\text { covenant }\end{array}$ & & $*$ & & * & * & $*$ & & * & \\
\hline 17 care of those left & & $*$ & & & $*$ & & & & \\
\hline $\begin{array}{l}18 \text { consolation to } \\
\text { inner circle }\end{array}$ & * & $*$ & & & & & & & \\
\hline 19 didactic speech & & & & & $*$ & & & & \\
\hline 20 ars moriendi & & & & & & & & & \\
\hline
\end{tabular}

Acts 20; Luke 22; 1 Macc 2:49-70; 1 Kgs 2:1-10; Deuteronomy 31-34; Joshua 23-24; 1 Sam 12:1-25; 1 Chronicles 28-29; Tob 14:3-11; Philo Vita Mosis 2.288-92; Josephus Ant. 4.8.45-49 \$\$309-31 (Moses); Ant. 12.6.3 \$\$279-84 (Mattathias); Plato Phaedo; Plutarch Cato Minor 66-70; Plutarch Otho 15-17; Diogenes Laertius Epicurus 10:16-18; (will 18-21, letter 22); Dio Oratio 30; Plutarch Anthony 75; Tacitus Annals 15:62-63 (Seneca); Tacitus Agricola 45; Plutarch Pericles 38-39; Plutarch Alexan$\operatorname{der} 73,76$. 


\begin{tabular}{|c|c|c|c|c|c|c|c|c|c|c|c|c|}
\hline VtM & JA4 & JA12 & Phd & PCM & POt & DLE & Dio & PAn & TAn & TAg & PPr & PA1 \\
\hline & $*$ & $*$ & & $*$ & $*$ & & & & & & & $*$ \\
\hline & & $*$ & $*$ & & & & & & $*$ & & & \\
\hline$(*)$ & & & $*$ & & & & & & & & $*$ & \\
\hline & $*$ & $*$ & $*$ & $*$ & $*$ & $(\mathrm{~L})$ & $*$ & $*$ & $(*)$ & $*$ & & $(\mathrm{P})$ \\
\hline & $*$ & $*$ & $*$ & & $*$ & $*$ & & & $*$ & & & \\
\hline & $(*)$ & $*$ & $*$ & $*$ & $*$ & & & $*$ & & $(*)$ & & \\
\hline & $*$ & $*$ & & & & & & & & & & \\
\hline & & & $*$ & $*$ & & & & & & & & \\
\hline & $*$ & $*$ & & & & $(\mathrm{~W})$ & & & & $(*)$ & & $*$ \\
\hline & & & & & & & & & & & & \\
\hline$*$ & $*$ & & & & & & & & & & & \\
\hline & $*$ & $*$ & & & & & & & & & & \\
\hline & & $*$ & & & & $(\mathrm{~W})$ & & & & & & \\
\hline$(*)$ & $*$ & $*$ & $*$ & & $*$ & & $*$ & $*$ & & $(*)$ & $(\mathrm{E})$ & $*$ \\
\hline & & $(\mathrm{N})$ & & & & & & & & & & \\
\hline & & & & & & & & & & & & \\
\hline & $*$ & & $*$ & & $*$ & $(\mathrm{~W})$ & & & $(*)$ & & & \\
\hline & $*$ & & $*$ & & & & $*$ & & & & & \\
\hline & $*$ & & $*$ & & & & $*$ & & $(*)$ & & & \\
\hline & & & $*$ & & & & & & & & & \\
\hline
\end{tabular}

For characteristics listed, see H.-J. Michel, Die Abschiedsrede... Apg 20, 17-38, and E. Stauffer, NT Theo (New York: Macmillan, 1956) App. 344-47.
* = presence of characteristic
$(\mathrm{L})=$ in letter, not speech
( ) implied or indirectly
$(\mathrm{W})=$ in the will, not speech
$(F)=$ example of the fathers
(E) $=$ in encomium, not speech
$(\mathrm{R})=$ future reversal
$(\mathrm{P})=$ by portents, not in speech
$(\mathrm{N})=$ degeneration now 


\section{Functions of the Farewell Address}

Part I has emphasized formal observations and shown that Luke 22:1438 shares generic features and structures of the "farewell address" in Greco-Roman and especially Greek OT examples. Acts 20 (also by Luke) and the biblical 1 Maccabees 2 and 1 Kings 2 are prime examples of this genre, and Luke 22 also seems to have been influenced by them for some of its structure and details. The summary chart demonstrates those common features in the Lucan, Greco-Roman, and biblical farewell addresses.

Part II will look at the manner in which and extent to which the formal generic dependencies of Luke 22 on these other writings also share the functions of this genre within the text and vis-à-vis Luke's readers. It will show that the similarities between Luke 22 and other examples of the genre of farewell speeches extend beyond mere literary polishing and stylistic imitation to having similar paraenetic and narrative functions for the author and in the account. Study of Luke's use of such generic forms will also provide further insight into the meaning of the difficult Luke 22:14-38.

What Eckhard von Nordheim says about testaments as a genre can for the most part be applied to smaller farewell addresses. The Sitz im Leben of the origins of testaments and farewell speeches seems to be ancient wisdom. The wisdom of the older person was valued and passed on to his sons or students. The expression "my sons," found in so much of this kind of writing, attests to its affiliation with wisdom literature. The farewell situation adds solemnity. Before leaving his sons or students, the father or teacher recalls to them the main elements of his life and teaching. The lessons of the past are preserved for the next generation. A major function of farewell addresses is therefore paraenetic. ${ }^{25}$

The chart in Part I (C) indicates the following elements to be especially common: (1) the summoning of successors, (2) the speaker's example, (3) his impending death, (4) an exhortation, (5) his warning and final injunctions, (6) his promises, (7) his appointment of a successor, (8) the mourning of his family and friends, (9) a sacrifice or the renewal of a covenant, (10) the care of those left behind, (11) consolations to an inner circle, (12) future degeneration. Though some of these are intrinsic to the situation of farewell or dying (\#\#3,8,10,11), several (\#\#1, 2, 47,12 ) imply a paraenetic setting.

As part of larger narratives, however, the speeches have additional

25 Nordheim, Lehre der Alten, 232-42, esp. p. 233. A testament cannot be a testament and be lacking in instructions for behavior, but it can be without either the recapitulation of the past or the announcements of the future. Nevertheless, those are major elements and cannot be considered secondary appendages to the form. Their intention is aimed at instructions for behavior, however. On "my sons" and sapiential literature, see Cortès, Adiós, 60-61. 
functions implied by these elements. The promises, appointing of successors, and renewing of covenant (\#\#6-7,9) imply a narrative function of legitimating successors. They show continuity from the beginning to the present. The solemn farewell situation emphasizes and grounds contemporary teaching and practice in the founder. Foretelling difficulties (\#\#5,12), especially defections from original teaching, can function as an apologetic, dissociating the founder from later "heretics."

Additional elements noted in many of the Greek OT examples are (a) the speaker's innocence and fulfillment of his mission, (b) tasks for the successors, (c) theological review of history, and (d) revelations about the future. All of these can function as justifying and illustrating the divine plan of history, developments after the founder's death, and the soundness of the foundation laid. In other words, these are historiographical functions in the narrative rather than paraenesis to the readers. Luke shares many of these narrative functions and concerns. He is not just preaching to his readers through the examples in the narrative.

\section{A. Paraenetic Functions}

Luke 22:14-38 functions paraenetically on two levels: the story and the readers. On the story level Jesus tells his disciples, "Do this in memory of me" ( $\mathrm{v} 19)$. He encourages the true spirit of authority and forbids them to lord it over those subject to them (vv 24-27). He gives Simon a mission ( $v$ 32) and warns the disciples to be ready (have a sword) for impending crisis (vv 36-37).

The paraenetic functions for Luke's readers probably reinforce the practice of the Eucharist in their assemblies, emphasize the true meaning of authority in the church, and likewise recall them to readiness.

\section{B. Historiographical Functions}

Within Luke's narrative, we can suggest four Lucan applications of historiographical functions common to the genre. The first is to show and justify the transitions of authority in the church from Jesus to the twelve. Similarly, the speech in Acts 20 demonstrates the transition from Paul to the churches' elders. This is part of the asphaleia Luke promised to Theophilus (Luke 1:4), showing how the present order is grounded in the founder. ${ }^{26}$

26 J. Roloff (Die Apostelgeschichte [NTD 5; Göttingen: Vandenhoeck \& Ruprecht, 1981] 302) discusses the Sitz im Leben of the farewell address. It gives to a group historical orientation through recollecting the heritage entrusted to them. It helps them understand their origins and how their heritage is determined by the past. It is important when historical continuity is problematic, especially in transition from the second to the third generation. Cf. the closest NT analogy to the Acts 20 speech, 2 Timothy and the pastorals in general (as well as Luke 22, John 13-17, 2 Peter). 
The second function is to recall the foundations of teachings and practices important to Luke's readers: the Lord's supper, the mode and meaning of Christian authority, and perhaps the change from the missionary practices found in the Jesus sayings. The first two are somewhat obvious. The third suggestion, about change in missionary tactics, may help to explain the puzzling vv 35-38. Commentators generally note how verse 35 refers back to the instructions to the seventy-two in Luke 10:4. ${ }^{27}$ But there is no consensus about the significance of these verses in context. Viewing them as part of a farewell address functioning within the two-volume narrative leads to the following suggestion: Paul's farewell address in Acts 20, which corresponds to Jesus' in Luke 22, holds up Paul's example of not seeking money from those he serves. Rather, the elders' work should give them the resources to help the weak (Acts 20:33-35). But Paul's practice of supporting himself contradicts the sayings of Jesus in the Gospels. Luke 9:3 and 10:4 tell missionaries to receive what they need from those to whom they minister. The Corinthian correspondence shows that Paul was attacked because of this. His approach was unlike Peter's, who did follow the sayings of Jesus and rely on church support (1 Cor 9:3-18). The problematic Luke 22:35-38 seems to lay an apologetic foundation for Paul's pastoral instructions in Acts 20. Aside from obvious reference to Jesus' passion and to future hostility to Christian missionaries, the positive meaning of these verses is disputed. But they certainly render the previous missionary instructions less absolute, and imply that changes in conditions can justify changes in methods. By undercutting the absolutism of the Gospel instructions, they implicitly defend the different approach of Paul and leaders of churches he founded from criticism.

A third historiographical function of the Luke 22 farewell speech is apologetic for the founders, vis-à-vis historical problems with Christianity. Apologetic for Paul's ministry is a dominant theme in the parallel Acts 20 speech. By demonstrating that Paul did everything possible for the Ephesian church but predicted later damage from false teachers, the speech explains decline in a Pauline church and absolves Paul from blame for it. ${ }^{28}$ Since Jesus was not attacked by Christians the way Paul was, the apologetic function of Luke 22 is different. By recalling that Jesus knew his betrayer and predicted Peter's fall, it showed that the fates of Judas and Peter were not due to Jesus' poor judgment in choosing disciples. Jesus' fate was determined by God, and Judas' action was necessary for it, yet culpable (Luke 22:21-22). Peter was caught in Satan's cosmic machinations against God's kingdom, but Jesus' prayer preserved him to succeed Jesus as leader. The speech adds the apologetic

27 E.g., Marshall, Luke, 824.

28 See Haenchen, Acts, 596; and Conzelmann, Apg, 126-27. 
note that Jesus' death was vicarious, "for you" (22:19-20), and underlies and is commemorated in the Eucharist. But unlike Acts 20, Luke 22 does not foresee decline after the founder's departure. On the contrary, Acts shows the same Spirit working in church leaders as in Jesus' ministry.

The future predictions in both Jesus' and Paul's farewell speeches have a fourth historiographical function in Luke-Acts. Prophecies show that there were no surprises in what happened to the church in later generations. God knew and prepared the church for what was to come. This is an important function in biblical historiography (e.g., in Deuteronomy 31-34; Joshua 23-24; Tob 14:3-11; Moses' farewell speech in Josephus, Ant. 4.8.45-49 $\$ 309-31)$. It is absent from the Greco-Roman examples studied.

These historiographical uses to which Luke put the genre of farewell address are similar to historiographical functions of other farewell addresses, especially in the Greek scriptures. Such uses of the genre in the Greek Bible seem to have provided models not only of the form but also of the uses to which the form can be put. Thus, transitions in authority are common in Greek biblical examples (e.g., Deuteronomy 31-34; 1 Macc 2:49-70; $1 \mathrm{Kgs} 2: 1-10$; 1 Chronicles 28-29) but not in the GrecoRoman passages studied, or in those from Josephus. 1 Macc 2:49-70 justifies the charismatic establishment of the Hasmonean dynasty in a time of oppression of Jews by analogy with the charismatic founding of David's dynasty during Philistine oppression. As Abraham, Joseph, David, and others in Mattathias's speech were freely chosen by God (rather than through dynastic succession), so was Mattathias. And as they designated certain sons as successors, so did Mattathias designate Simon ruler and Judas field general. From Simon through John Hyrcanus, with whom the book ends, came the Hasmonean dynasty which the book endorses. $1 \mathrm{Kgs}$ 2:1-10, part of the Deuteronomic history, legitimates the transfer of power from David to Solomon and Solomon's early actions against Joab and Shimei. It also functions as a theodicy linking the eventual fall of the Davidic kingship to disobedience of his successors.

\section{Conclusions}

Although mostly traditional sayings make up Luke 22:14-38, this article has illustrated how they combine to form a farewell address. It found many common farewell elements with the frequently imitated final dialogue of Socrates in Plato's Phaedo, as well as with biblical farewell addresses. But though other Greco-Roman writings imitated Socrates' last dialogue, few can be found that have any extensive farewell address sharing these elements. Most merely give the person's "last word" (usually a clever epigram) and describe his or her death.

We have tried to avoid any dichotomy between Hellenistic and biblical writing. But we have distinguished two different traditions of 
farewell addresses and have found that Luke 22 and Acts 20 imitate the biblical more than the secular Greco-Roman speeches. 1 Macc 2:49-70 and $1 \mathrm{Kgs}$ 2:1-10 seem to have had a special influence on the motifs, structure, and vocabulary of Luke 22 .

Luke 22:14-38 also has functions similar to those of biblical farewell speeches. Besides the paraenetic functions common to most farewell speeches, it also has standard historiographical functions, like showing transitions in authority and changing circumstances that justify changes in practice. It functions apologetically by stressing Jesus' prophecies of denials and setting what happened in the context of God's will.

Viewing the whole of Luke 22:14-38 as an example of the biblical farewell address contributes to the solution of the following problems that remain after synoptic comparison, source studies, and focus on the individual pericopes. Especially, it relates and makes sense of apparently unrelated pericopes. For example, it gives a reasonable answer to much speculation about the cup-bread-cup order and manuscript problems, speculation that tries to explain why statements about desiring to eat the passover and drink wine one last time precede the Eucharist passage.29 A farewell address could hardly begin with the eucharistic words, so these others were prefixed to indicate clearly the situation of a final meal and impending death. Nor could one expect the prediction of Judas' betrayal to begin a farewell address, so it is moved to later in the scene than in Mark. The genre of farewell address also helps to explain Luke's placing of the dispute over greatness: though it seems so out of place when viewed as an isolated pericope, it introduces paraenesis, an expected aspect of farewell speeches. By moving paraenesis on Christian authority to this solemn setting, Luke is implying that Jesus devoted his last teaching to it, thus underlining its importance.

Other puzzling aspects of Luke 22:14-38 are also found to be common elements of the genre of farewell address. The misunderstanding of disciples is common to dialogues in general and farewell dialogues in particular. Promises and successions of authority are standard in biblical farewell addresses. Jesus' bequeathing to his disciples the kingdom his Father had bequeathed to him fits the genre. The prediction about Simon suits the genre as warning of coming problems. And the peculiar statement about having a purse and sword illustrates the new situation after the founder's death, a reversal as from David's reign to Solomon's regarding the punishment of Joab and Shimei. It also clears away a major objection to Paul's missionary style and thus prepares for the apologetic of the Pauline farewell speech in Acts 20.

29 See Marshall, Luke, 797-807; and Ernst, Lukas, 582-89, with their bibliographies. 


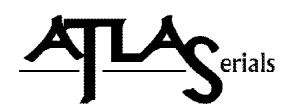

Copyright and Use:

As an ATLAS user, you may print, download, or send articles for individual use according to fair use as defined by U.S. and international copyright law and as otherwise authorized under your respective ATLAS subscriber agreement.

No content may be copied or emailed to multiple sites or publicly posted without the copyright holder(s)' express written permission. Any use, decompiling, reproduction, or distribution of this journal in excess of fair use provisions may be a violation of copyright law.

This journal is made available to you through the ATLAS collection with permission from the copyright holder(s). The copyright holder for an entire issue of a journal typically is the journal owner, who also may own the copyright in each article. However, for certain articles, the author of the article may maintain the copyright in the article. Please contact the copyright holder(s) to request permission to use an article or specific work for any use not covered by the fair use provisions of the copyright laws or covered by your respective ATLAS subscriber agreement. For information regarding the copyright holder(s), please refer to the copyright information in the journal, if available, or contact ATLA to request contact information for the copyright holder(s).

About ATLAS:

The ATLA Serials (ATLAS $®)$ collection contains electronic versions of previously published religion and theology journals reproduced with permission. The ATLAS collection is owned and managed by the American Theological Library Association (ATLA) and received initial funding from Lilly Endowment Inc.

The design and final form of this electronic document is the property of the American Theological Library Association. 